\title{
Os tipos de investimentos no âmbito das startups
}

\author{
The types of investments in the scope of startups \\ Los tipos de inversiones en el ámbito de las startups
}

Recebido: 08/03/2021 | Revisado: 15/03/2021 | Aceito: 15/05/2021 | Publicado: 01/06/2021

\author{
Torben Fernandes Maia \\ ORCID: https://orcid.org/0000-0003-3053-3062 \\ Universidade de São Paulo, Brasil \\ E-mail: torben@paulomaia.adv.br \\ Paulo Antônio Maia e Silva Junior \\ ORCID: https://orcid.org/0000-0003-0846-0952 \\ Universidade Federal da Paraíba, Brasil \\ E-mail: paulojr@paulomaia.adv.br \\ José Cândido da Silva Nóbrega \\ ORCID: https://orcid.org/0000-0002-0976-3763 \\ Universidade Federal de Campina Grande, Brasil \\ E-mail: jcandidosn@uol.com.br \\ Francisco das Chagas Bezerra Neto \\ ORCID: https://orcid.org/0000-0001-6232-4383 \\ Universidade Federal de Campina Grande, Brasil \\ E-mail: chagasneto237@gmail.com
}

\begin{abstract}
Resumo
O presente estudo vislumbra analisar alguns apontamentos acerca do tipos de investimentos no âmbito das startups, sobretudo no que tange o crescimento econômico e a melhor forma de investir, tendo em vista que num modelo de negócios completamente desconhecido e incerto, mas que tem grande potencial lucrativo, escalável e disruptivo. Nessa perspectiva, este artigo, através da pesquisa exploratória, de natureza qualitativa, método dedutivo, coleta de dados documental e bibliográfica, procedeu-se de modo a realizar uma análise minuciosa do arcabouço normativo que trata acerca das startups. Não obstante, foi pontuado a extrema relevância do aspecto jurídico na seara empresarial, como forma de viabilizar a proteção, segurança e qualidade negocial para o financiamento, buscando desenvolver o ecossistema de startups brasileiro. Dessa maneira, diante da problemática exposta, buscou-se, elucidar, que a startup precisará de capital de terceiros para começar a operar. Ademais, foi destacado o grau de relacionamento entre o investidor e o investido nessa qualidade de financiamento, principalmente no tocante ao investidor anjo e o tradicional. Palavras-chave: Investimento; Startups; Crescimento econômico.
\end{abstract}

\begin{abstract}
The present study analyzes some notes about the type of investments in the scope of startups, especially with regard to economic growth and the best way to invest, considering that in a completely unknown and uncertain business model, but which has great profit potential, scalable and disruptive. In this perspective, this article, through exploratory research, of a qualitative nature, deductive method, collection of documentary and bibliographic data, proceeded in order to carry out a thorough analysis of the normative framework that deals with startups. Notwithstanding, the extreme perfection of the legal aspect in the business field was pointed out, as a way of making possible the protection, security and business quality for financing, seeking to develop the Brazilian startups ecosystem. Thus, in view of the exposed problems, it was sought to clarify that a startup needs third party capital to start operating. In addition, the degree of relationship between the investor and the investee in this quality of financing was highlighted, especially with regard to the angel investor and the traditional investor.
\end{abstract}

Keywords: Investment; Startups; Economic growth.

\section{Resumen}

El presente estudio analiza algunas notas sobre el tipo de inversiones en el ámbito de las startups, especialmente en lo que respecta al crecimiento económico y la mejor forma de invertir, considerando que en un modelo de negocio completamente desconocido e incierto, pero que tiene un gran potencial de rentabilidad, escalable y disruptivo. En esta perspectiva, este artículo, a través de una investigación exploratoria, de carácter cualitativo, método deductivo, recolección de datos documentales y bibliográficos, procedió a realizar un análisis exhaustivo del marco normativo que se ocupa de las startups. No obstante, se señaló la extrema perfección del aspecto legal en el ámbito empresarial, como una forma de posibilitar la protección, seguridad y calidad empresarial del financiamiento, buscando desarrollar el ecosistema de startups brasileñas. Así, ante los problemas expuestos, se buscó aclarar que una startup necesita capital 
de terceros para comenzar a operar. Además, se destacó el grado de relación entre el inversor y la participada en esta calidad de financiación, especialmente en lo que respecta al inversor ángel y al inversor tradicional.

Palabras clave: Inversión; Inauguración; Crecimiento economico.

\section{Introdução}

O conhecimento da técnica jurídica é de fundamental importância quando da abertura de uma empresa, posto que pode evitar uma série de eventuais infortúnios, que muitas vezes poderiam ter sido prevenidos, em função de determinadas opções feitas pelos fundadores de empresas se soubessem das diversas opções ofertadas pela legislação, teriam feito a que lhe fosse mais interessante em diversos aspectos.

Infelizmente, é comum na prática empresarial, e em menor escala, até no campo de investidores, não atribuir às questões jurídicas a importância devida, muito embora esses sejam quesitos que também fazem parte dessa complexa atividade, onde é comum aos condutores desse processo concentrar as atenções exclusivamente na parte operacional e atividade-fim da companhia, no desenvolvimento e venda dos seus produtos e/ou serviços, utilizando-se de consultas ou assessorias jurídicas apenas quando problemas aparecem.

Além do mais, muitos desses problemas, se aparecerem, podem levar a empresa à bancarrota ou desestruturá-la completamente demandando tempo considerável para uma reestruturação, a exemplo de questões societárias mal resolvidas, resultado de escolhas preliminares malfeitas ou redações jurídicas incompletas, ambíguas ou irregulares. Isso, porque as consequências sempre desaguam no coração de qualquer instituição: a estrutura financeira.

Segundo a radiografia das startups brasileiras realizada pela Associação Brasileira de Startups e a ACCENTURE (maior empresa de consultoria em gestão e tecnologia da informação do mundo), 30\% das empresas que participaram da análise informaram não estarem formalizadas, portanto, sem o respectivo registro no CNPJ. Ou seja, sem os benefícios concedidos às pessoas jurídicas, inclusive a proteção legal feita sobre o patrimônio da pessoa física dos sócios em distinção ao da corporação.

É dentro dessa lógica que as startups, como empresas inovadoras que possuem grande potencial disruptivo, atuando com produtos e serviços escaláveis, possuem capacidade de crescimento altíssima, tornando-se um gigantesco atrativo financeiro para investidores. Nessa esteira, ingressa o aspecto jurídico, viabilizando a proteção, segurança e qualidade jurídica para o financiamento, buscando desenvolver o ecossistema de startups brasileiro.

Exatamente como pensa Bruno Feigelson, Erik Fontenele e Victor Fonseca, quando oportunamente afirmaram que "o Direito também funciona como elemento atrativo para investimento: uma proteção jurídica de qualidade, interna ou externa, auxilia na estruturação e solidez empresarial" (Feigelson, Fontenele, \& Fonseca, 2018, p. 41).

Diante da problemática exposta, será realizada uma pesquisa exploratória, que tem por objetivo proporcionar uma maior familiaridade com o problema. Sem a perspectiva de esgotamento do tema, tratar-se-á, sobretudo, acerca dos tipos de investimentos na seara das startups. Ademais, se utilizará do método de abordagem dedutivo, uma vez que se buscará os resultados a partir da análise geral até concluir de maneira particular a hipótese. Quanto à natureza da pesquisa, esta será qualitativa, buscar-se-á analisar e interpretar os institutos do Direito Empresarial, como forma de chegar à conclusão que as startups são de extrema relevância para o crescimento econômico internacional e nacional.

Quanto ao método de procedimento, atribuir-se-á o método monográfico, partindo de um estudo profundo sobre as startups, que podendo esta pesquisa ser considerada representativa de muitos outros ou mesmo de todos os casos semelhantes. Além do mais, quanto aos procedimentos técnicos, se delineará o presente estudo por meio de pesquisa bibliográfica e documental, tendo em vista que se buscará, através da renomada doutrina do direito e periódicos especializados, bem como através da interpretação das leis, a solução para impulsionar o desenvolvimento econômico. 
Nessa senda, sabendo da importância que deve ser dada às questões societárias, julga-se relevante encarar previamente as opções de investimento em startups que podem ser acionadas. Dessa forma, portanto, serão apresentados alguns apontamentos acerca dos tipos de investimentos no âmbito das startups.

\section{Desenvolvimento}

É preciso destacar o benefício tributário trazido pela Lei Complementar 167 de 2019 em seu art. 9. Segundo a inteligência desse dispositivo, todas as vezes em que houver a capitalização de recursos por uma startup, desde que esses valores sejam destinados a desenvolvimento dos projetos da empresa, esses montantes não devem ser considerados como renda, e, portanto, afastando a constituição do crédito tributário na modalidade de imposto de renda.

Houve a concessão de isenção tributária, que deve ser destaca no começo desse tópico, posto que ele se destina a discutir de maneira geral as diversas hipóteses existentes para se investir e startup. Diferentemente do que ocorre com a Lei Complementar 155 de 2016, que concede benefícios apenas para os contratos de investimento-anjo que ocorrem na modalidade de contrato de participação, o benefício concedido pela LC 167 é geral e abstrato, havendo, portanto, uma intepretação presuntiva de que tal graça é de aplicabilidade para todas as modalidades de capitalização de recursos.

Assim, todas as espécies de investimentos que serão abordadas a partir de agora, entende-se que foram agraciadas pelo subsídio do art. $8^{\circ}$ da LC 167/2019.

Nessa esteira, cabe pontuar que financiar uma empresa com capital próprio é fase obrigatória pela qual toda empresa passa. Isso porque capital deve ser compreendido em seu sentido lato, seja na concepção financeira do termo, ou através de bens imateriais, a exemplo de dedicação pessoal, tempo, psicológico na construção e realização do projeto.

Assim, em algum momento todo empreendedor financia a sua empresa com capital próprio. É possível e provável que posteriormente se busque financiamento externo, seja ele de ordem financeira e/ou investimentos imateriais, chamado de smart money.

Dessa feita, financiar uma empresa com capital próprio pode ocorrer através de recursos financeiros, em que o empresário pessoa física utiliza seu patrimônio pessoal, e injeta valores na pessoa jurídica criada por ele, a modalidade mais comum de financiamento.

O Bootstrapping é a modalidade de financiamento interno, ou autofinanciamento, onde os fundadores da startup passam a investir na companhia com o capital próprio, termo que deve ser compreendido em seu conceito amplo, seja como estrutura financeira ou imaterial. É, talvez, a espécie mais utilizada nesse ecossistema, podendo ser configurada quase como que uma passagem obrigatória, uma vez que o histórico dessas empresas é um início de atividades marcadas pela carência de capital financeiro.

O termo bootstrap é de origem inglesa, cuja tradução literal quer dizer "alça de bota", uma referência àquele pedaço de tecido presente nas botas localizado acima do calcanhar, que facilita o calçamento dessa. No entanto, a sua utilização no meio empresarial é feita através de analogia com a metáfora de "levantar a si próprio pelas alças da bota", usado no século XIX para fazer menções ao ato de realizar tarefas impossíveis, como "pular uma cerca alta puxando suas próprias botas com as mãos" (Gitahy, 2018). 
Figura 1 - Mera ilustração de alça de bota.

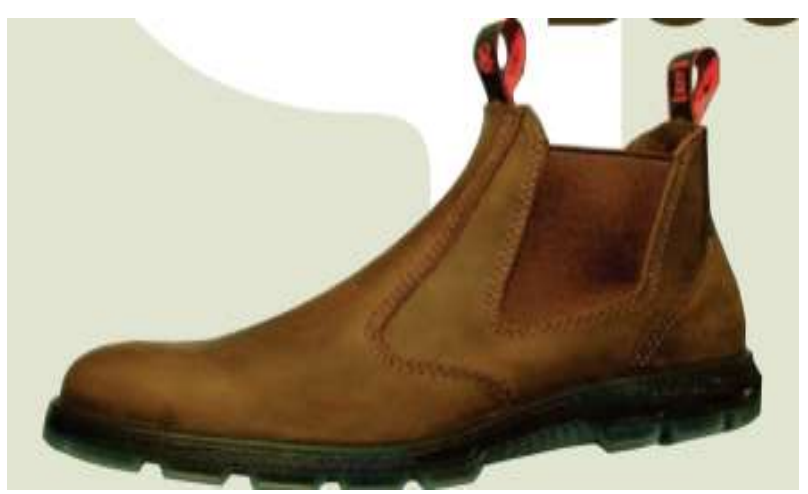

Fonte: Condé (2015).

Esse cenário acentuado de grandes riscos e incertezas de startups faz com que a captação de investimentos externos se torne uma opção ainda mais tortuosa. Mas, para que as operações não fiquem paradas em função de ainda não dispor de recursos humanos profissionalizados para exercer as funções necessárias, os membros da startup passam a utilizar o investimento interno de bootstrapping ${ }^{l}$.

Sua utilização no ecossistema de startups está diretamente ligada à prática de buscar o maior rendimento da equipe, diante da menor quantidade de custos possíveis, fazendo com que explorem ao máximo as habilidades e ferramentas pessoais de cada colaborador da empresa. Assim, inicia-se a empresa sem a busca de um financiamento externo, esgotando todas as possibilidades de autofinanciamento ou do financiamento interno, através de recursos próprios. O caixa apertado é marca em boa parte dessas empresas, e muitas vezes o único financiamento disponível é o improviso de ferramentas disponíveis dentro da própria equipe. $\mathrm{O}$ foco é tirar o projeto idealizado do papel, ainda que não se disponha de muitos recursos para isso.

A grande vantagem em se utilizar dessa modalidade de financiamento consiste no fato de que não há onerações consideráveis para a startup, bem como não há divisão de partes da empresa com os financiadores. Os fundadores não precisam prestar contas ou se submeter a outros sócios ou investidores externos, tornando as decisões mais centralizadas e ágeis, ficando livres para decidir como acharem mais interessante, pois possuem o controle total da empresa.

Existem dois métodos clássicos para se praticar o bootstrapping. Um deles é o Doble Journey, ou jornada dupla, onde o fundador dá início a sua startup em paralelo a outro emprego que possui, utilizando aquela fonte de renda pessoal para manter os custos da empresa. É a opção adotada por aqueles empreendedores que optam por não abandonarem tudo, e tentam administrar as duas atividades laborais, contudo, pagam um preço altíssimo em suas vidas pessoais.

A segunda modalidade é a stocking, onde o empreendedor começa a poupar o seu salário mensal, a fim de construir uma reserva financeira considerável e suficiente para startar e manter o seu negócio (Viana, 2018). É o all in, expressão do esporte poker que faz menção ao fato de apostar todas as suas fichas em uma jogada. Em analogia com as startups, seria uma jogada de risco extremamente alta, mas que no futuro pode ser muito recompensadora, dada a característica escalável dessas companhias.

São exemplos de bootstrap o aproveitamento de habilidades pessoais de cada colaborador, seja para gerir, fazer o marketing, o business plan, as operações financeiras, conhecimentos jurídicos e inúmeras outras habilidades; ou a utilização de cartões de crédito pessoa física ou até mesmo o compartilhamento de equipamentos e recursos humanos de outras empresas (Feigelson, Fontenele \& Fonseca, 2018, p. 78).

${ }^{1}$ Bootstrapping consiste na prática de explorar ao máximo a capacidade individual de cada um dos fundadores da empresa, visando à maximização dos resultados com o menor custo possível (Feigelson, Fontenele, \& Fonseca, 2018, p. 78). 
Assim, caso um colaborador tenha conhecimentos sobre programação, ele passa a improvisar a construção do endereço eletrônico, o desenvolvimento da plataforma, se for o caso, ou construção do que for preciso, dentro dessa área de atuação. Se outro membro do time tiver vocação para vendas, ele passa a exercer a função comercial com base no tato.

A desvantagem desse tipo de financiamento consiste no fato de operar sobre uma vulnerabilidade muito grande, fazendo com que seus colaboradores não disponham de muita margem para erro, com cargas de trabalho excessivas e gerindo o negócio sob pressão psicológica elevada, seja pela inexperiência ou pelo risco acentuado, posto que eventual deslize possa levar o negócio à bancarrota.

Registre-se ainda que o bootstrapping pode consistir apenas em uma fase temporária na história da startup, em que ela inicia suas atividades baseada por esse modelo em virtude de inexistir outra opção, até desenvolver o seu protótipo, alcançar o MVP e se lançar num crowdfunding, na busca de um investimento externo.

O financiamento externo é etapa fundamental na vida de uma startup, sendo em muitos casos o elemento capaz de tornála escalável e levá-la à sua consolidação no mercado. Essa espécie de investimento é assim nomeada, por ser o gênero do qual todos os recursos a serem injetados são providos por terceiros alheios ao grupo que compõe a empresa, seja ele de origem financeira, humana ou social na companhia.

Muitas vezes o que a companhia necessita é mais do que estrutura monetária, mas também de logística, de experiência administrativa, conhecimento de mercado, network, know-how, entre outros, o que faz com que em alguns casos, as startups optem pela presença de um sócio que venha agregar esse material humano e intelectual, trazendo um smart money de muito valor agregado para a companhia, como iremos abordar em tópico específico, que é o que muitas os investidores-anjos têm para agregar.

É sobre isso que o presente tópico aborda, as modalidades de financiamento externo mais importantes e que são muito utilizadas no ecossistema das startups, antes de adentrar àquela que mais interessa a esta dissertação. É que o fundraising (captação de investimento) de startups é repleto de particularidades, de maneira que se faz necessária a compreensão desse universo para uma assimilação plena das discussões que são levantadas neste trabalho.

A intenção dos founders é inicialmente operar baseado em financiamento interno buscando otimizar os custos e maximizar os resultados, partir para um financiamento externo, participando de rodadas de investimentos para que possam tornar-se escaláveis e que consigam atingir o breakeven point, tornando a empresa rentável e capaz de operar de maneira autônoma, pois nesse patamar os custos são menores do que a arrecadação através da venda de seus produtos e/ou serviços.

Para alguns, o ponto de equilíbrio é alcançado rapidamente. Em outros casos, porém, alguns deles muito famosos, demora tempo considerável. É o que acontece, por exemplo, com a Uber. Startup global e pioneira no mercado de aplicativos de corridas de transporte, fundada em 2009 no Vale do Silício - EUA² e presente em mais de 70 países, mas que até o presente momento ainda não conseguiu se tornar uma empresa lucrativa, fazendo com que nos dias atuais o caixa da empresa precise ser socorrido por financiamentos externos para poder fechar o balanço (Uber, 2018).

No ano de 2017, essa companhia viu seu prejuízo aumentar 60,7\% e alcançar perdas de US\$ 4,5 bilhões (Loureiro, 2018), repetindo um resultado negativo do ano anterior. Ainda assim, o mercado a enxerga com bons olhos, fazendo sobre ela um valuation (avaliação de mercado) de US\$ 72 bilhões. Pode-se falar ainda sobre a Tesla, empresa automotiva independente que desenvolve, produz e vende veículos elétricos. Foi fundada em 2003, mas até 2017 não havia alcançado o seu ponto de equilíbrio, apresentando resultados financeiros nada motivantes para investidores. Contudo, isso não foi empecilho para que financiadores se mantivessem animados quanto ao futuro dessa companhia (Tesla, 2018), e continuem a injetar bilhões de dólares.

${ }^{2}$ https://www.uber.com/pt-BR/about/ 
No mercado tradicional, investir quantias financeiras significativas em companhias que já possuem anos de fundação e que não conseguiram se tornar lucrativas, mesmo depois de anos de operação e apresentam resultados financeiros negativos, soa como irracional. Todavia, existem aqueles que encaram como investimentos que a longo prazo têm grande potencial de apresentar resultados fantásticos, pois são companhias que lidam com inovação e soluções que podem ser a regra para o futuro.

A Uber, por exemplo, é uma empresa cujos produtos já são amplamente consumidos, gerando um volume de caixa gigantesco, na casa dos bilhões de dólares, mas insuficiente para produzir um saldo positivo. Ou a tesla, que embora não tenha saúde financeira equilibrada, a sua projeção futura é de que será uma das maiores companhias do mundo, haja vista o seu produto ser a aposta para qual a humanidade se encaminha, que é a utilização exclusiva de automóveis elétricos ${ }^{3}$, em homenagem ao patrimônio ambiental do planeta.

FFF (Friends, Family e Fools) é um conjunto de termos de origem inglesa que faz menção à sequência desses três players que muitas vezes são os primeiros a serem abordados pelo fundador de uma startup para a captação dos recursos financeiros básicos para dar corpo à ideia. Assim, "FFF" é uma sigla que faz menção aos amigos, família e tolos (desavisados), que muitas vezes são os primeiros a serem abordados por startups nas suas lutas para tirar uma ideia do papel e trazê-la para o mundo real. Por serem pessoas que são próximas dos founders ou por desejarem e acreditarem no sucesso e viabilidade do projeto, acabam investindo certa quantia na ideia, que geralmente são valores menores, quando comparados com outras quantias investidas por outras modalidades de investidores externos.

Comumente, o momento da captação desses recursos ocorre numa fase de total informalidade jurídica da empresa, onde os valores são recebidos antes mesmo da existência de um contrato social e não é feita formalização do investimento. Dessa forma, percebe-se que a regra é uma startup ter o FFF como o primeiro estágio de financiamento.

A sequência do fundraising ordinário, seria essas empresas captarem recursos em investidores-anjos. Contudo, por opção didática, opta-se por abordar esse tipo de financiamento ao final desse tópico, a fim de ir cada vez mais delimitando as discussões no presente trabalho, até adentrar ao seu ápice.

A Venture capital $(V C)$ e private equity $(P E)$ consistem em modalidade de financiamento na qual investidores ingressam em um fundo de investimento mediante aportes de valores e constituem um patrimônio, onde esse montante formado será utilizado para investir, mediante aquisição de ações de empresas que não operam na Bolsa de Valores (mercado público de ações).

Os fundos recebem valores dos investidores, e fazem a injeção de recursos nas empresas. Por sua vez, as investidas entregam participação societária ou título de crédito (Equity, debt, entre outros) que, ao final da operação, geram um lucro que é repassado aos investidores.

${ }^{3}$ Nesse sentido, a Alemanha já tem legislação nacional aprovada proibindo a utilização a partir de 2030, de carros movidos a combustão interna. A Noruega segue o mesmo caminho, e já proibiu a partir de 2025. A França, o Reino Unido, a Holanda e a China também já discutem projetos nesse sentido. Disponível em: <https://www1.folha.uol.com.br/mercado/2017/08/1907190-os-planos-para-proibir-carros-diesel-e-a-gasolina na-europa-sao-realistas.shtml>. Acesso em: 11 out. 2020. 
Figura 2 - Fluxograma da operação de investimento através de Private Equity/Venture Capital .

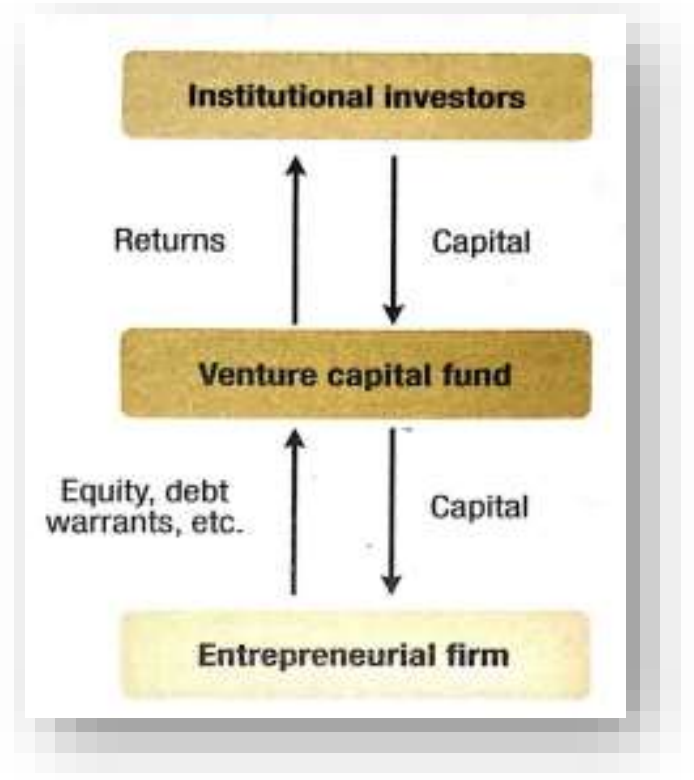

Fonte: Cumming \& Johan (2009) apud Feigelson, Fontenele \& Fonseca (2018), p. 101.

Por se tratar de empresas que possuem o capital fechado, a negociação é feita entre investidor/fundo de investimento e o administrador/gestor da empresa que será investida. Em função dessa burocracia, quando se compara com a compra e venda de ações na bolsa de valores, a liquidez dessas quotas é bem mais baixa, e o retorno é gerado a médio e longo prazo.

Há também assimetria informacional, que faz com que o risco da operação seja elevado, mas que o retorno recebido pelos investidores também seja (Agência Brasileira de Desenvolvimento Industrial, 2011).

O venture capital, em tradução livre para o português, é capital aventureiro. É assim chamado, vez que o risco nessa modalidade de fundo de investimento é maior do que no PE. O VC está mais próximo daquelas empresas que ainda estão focadas numa operação menor, pois estão na briga para se estruturarem.

São aquelas startups que estão focadas em virar a chave para poder alavancar ainda mais o seu negócio. Podem já ter passado pelo investimento-anjo, por aceleradora ou incubadora, e tiveram bons resultados. Mas não estão ainda com o negócio tracionado. Muitas vezes já dispõem de faturamento e certa estrutura, mas estão precisando de recursos para ficarem ainda maiores e mais estruturadas. Estão lutando para tornarem o seu crescimento exponencial. Assim, estão na busca por mais um andar de escritório para expandir sua estrutura, ou adquirir uma tecnologia que custa caro e pode potencializar a sua produção e operação.

A PE, por sua vez, é direcionada para as startups que estão em outra fase. São aquelas startups que já estão interessadas em adquirir outras empresas que concorrem com elas ou que são importantes para as suas cadeias de operação. Ou que estão na busca por um investimento que possibilite abrir o seu capital na bolsa de valores (realizar o IPO), ou internacionalizar sua empresa. Elas já dispõem de altos valores em seus caixas, mas querem se tornar gigantes. Até já se encontram consolidadas no mercado, fazendo com que exista um interesse maior nos investidores, posto que o risco é menor, quando comparada com as empresas que ainda estão buscando o tracionamento e a consolidação, o caso das VC.

A PE termina sendo o último nível, vez que há uma presença maior do volume financeiro aportado. É o caso de bancos e fundos bilionários de investimento, que não estão dispostos a correr os mesmos riscos dos VC.

Segundo a Agência Brasileira de Desenvolvimento Industrial (2011), a distinção entre o Venture Capital e o Private Equity se dá mediante os estágios de desenvolvimento de cada empresa, as quais a Agência dividiu em: desenvolvimento, 
expansão e maturidade. O VC ocorre no momento em que a empresa está na fase do desenvolvimento, a mais embrionária das três, e com riscos maiores de sucesso, o que a torna mais próxima dos mercados das startups, embora o PE também esteja ligado.

O PE ocorre na fase em que a empresa está passando pela expansão ou maturidade, nomeados respectivamente por private equity - growth, e private equity - later stage (Feigelson, Fontenele \& Fonseca, 2018).

A modalidade de captação de investimento através da bolsa de valores se dá através da abertura do capital fechado da empresa para negociação no mercado de ações. Assim, a startup abre o seu capital social e a oferta no mercado de ações da bolsa de valores para que sejam negociadas. Essa abertura de capital é chamada de Initial Public Offering (IPO), que faz referência a essa oferta pública inicial que marca o início das negociações públicas de ações da empresa.

No Brasil, temos uma Bolsa de Valores de São Paulo (BOVESPA), cuja sistemática é regulada pela Comissão de Valores Mobiliárias (CVM), autarquia vinculada ao Ministério da Fazenda, e que é responsável por disciplinar e regular esse mercado. A empresa deve possuir 100\% das ações ordinárias, dispor de uma governança corporativa e de um compliance inserido e bem trabalhado na sua estrutura.

No mundo, existem inúmeras bolsas de valores ${ }^{4}$. Para ingressar no mercado de ações públicas, é preciso que a empresa que irá realizar o IPO se submeta a uma série de requisitos que são estabelecidos pelos respectivos órgãos de regulação.

Assim, é feita uma valuation da startup, e com base nos valores levantados por essa avaliação do seu valor de mercado, a empresa faz uma oferta sobre parte do seu capital social perante a bolsa de valores.

Para que uma startup esteja realizando um IPO, isso é sinal de que ela, provavelmente, consolidou-se no mercado, já apresentou um crescimento escalável, e muitas vezes até já passou por outras rodadas de investimentos, a exemplo do investimento-anjo, VC, PE entre outros. Contudo, o volume de recursos que ela precisa injetar na companhia para seguir crescendo é muito alto, e ela pode arrecadar através do mercado de ações.

Incubadora é um termo originalmente ligado ao dispositivo que simula condições ideais de temperatura, utilizado para recém-nascidos que quando do parto precisam se adaptar ao mundo fora da barriga da mãe. No universo empresarial, a lógica segue a mesma, onde as incubadoras são ligadas a estruturas físicas que acolhem empreendedores em estágio inicial de desenvolvimento de suas ideias, e buscam fornecer o apoio mínimo necessário, a custos baixos, para a empresa se desenvolver e sair para encarar o mercado.

A sua aplicação está ligada diretamente àquelas startups que ainda estão na fase inicial e embrionária do negócio, sem ter feito ainda a validação do problema e a respectiva solução, e, consequentemente, ainda não dispõe de um MVP. Assim, não há aportes financeiros nem a cobrança de equity por usufruir do espaço.

Incubadoras estão vinculadas a instituições de pesquisas e ensino que acolhem negócios e projetos que estão em suas fases iniciais, e lhes possibilitam a instalação em determinado espaço, sem cobrar equity. Todavia, não há aporte de recursos, mas se proporciona à empresa que está numa fase embrionária um espaço para trabalhar e a oportunidade para a realização de um network de ordem técnica.

Assim, não há mentorias ou consultorias ofertadas diretamente às startups pelos incubadores, mas no espaço da incubação há presença de outras pessoas, empresas e profissionais, que podem vir a contribuir bastante em diversos setores que a empresa incubada está necessitando desenvolver. Segundo Paul Miller e Kirsten Bound, foi o interesse crescente do setor privado sobre o nicho de startups que provocou um desenvolvimento considerável das incubadoras nos últimos anos:

${ }^{4}$ Só nos Estados Unidos, existem duas bolsas: a NASDAQ - National Association of Securities Dealers Automated Quotations, e a NYSE Euronext que é um mercado que conglomera o norte-americano, belga, francês, holandês, português e inglês. Juntas, essas duas bolsas capitalizam mais de trilhões de dólares. O comum é cada país possuir o seu mercado interno de ações mobiliárias de empresas. 
[...] o trabalho de uma incubadora evoluiu de uma forma de ajudar as empresas a sobreviverem em seus anos de formação (diminuindo o risco de queda) a uma de adicionar valor às empresas (aumentando a vantagem positiva) (Miller \& Bound, 2011, p. 3, tradução nossa). ${ }^{5}$

Além do mais, existem empresas que sua finalidade é apenas hospedar qualquer pessoa física ou jurídica que queira explorar a sua estrutura. Embora existam aqueles que optam por oferecer a estrutura física em troca de eventual participação societária, existem aqueles que querem apenas alugar um espaço.

O interesse em se instalar nesses espaços também consiste no fato de eles serem vitrines para investidores que muitas vezes direcionam os seus olhares para esses locais, pois sabem que é um ninho de potenciais empresas lucrativas. A importância delas está ligada ao fato de serem instituições acolhedoras que visam qualificar startups para torná-las elegíveis para o financiamento externo. A captação de investidores, a recepção de financiamentos externos está diretamente ligada ao fato de agentes se interessarem pela companhia, devido ao fato de verem nela um potencial de retorno financeiro interessante no futuro.

É preciso demonstrar viabilidade, capacidade de crescimento, organização, conhecimento do mercado e uma série de outros requisitos, que, no conjunto da obra, transmitem confiança para os financiadores injetarem dinheiro nessas empresas.

Por sua vez, a aceleradora é uma empresa que está disposta a injetar recursos financeiros em uma startup em troca de equity, proporcionando o acesso a mentorias específicas e qualificadas nas diversas áreas, a exemplo da financeira, administrativa, jurídica e de TI, colocando a empresa acelerada em contato com pessoas experientes, que estão inseridas no ecossistema.

Muitas vezes, as aceleradoras também possuem uma rede de contatos que pode agregar valor a essas empresas, através de redes de distribuição já consolidadas, know-how e um smart Money, que terminam por fortalecer e levar essas firmas a patamares a que elas poderiam não chegar ou demorariam muito tempo para alcançar.

$\mathrm{Na}$ aceleração, as startups são submetidas a um pacote de serviços, que vão desde consultorias empresariais, assessorias jurídicas para construção do seu background legal, e que proporcionam uma abreviação de um caminho que seria percorrido arduamente pelos fundadores, onde a moeda de troca é a cessão de parte da sociedade, para que num futuro, em eventual sucesso dessa empresa, a aceleradora possa ganhar em cima do lucro decorrente da valorização das aceleradas.

O tempo de uma aceleração dura em média de 3 a 12 meses e o valor do investimento realizado é entre $\mathrm{R} \$ 10.000,00$ (dez mil reais) e $\mathrm{R} \$ 100.000,00$ (cem mil reais) (Abraii, 2018), onde a média do equity cobrado gira em torno de 10-20\% do quadro social.

O instrumento jurídico que operacionaliza tudo isto é a dívida conversível (Abraii, 2018), que faz com que as startups emitam dívidas que se convertem em participação societária quando do vencimento, em função do investimento realizado por incubadoras e aceleradoras, considerando o tempo em que foram qualificadas por essas instituições.

As aceleradoras auxiliam os empreendedores na construção do MVP a identificar os clientes do produto/serviço, onde se encontram e como captá-los, fornecendo uma quantia de capital, mentoria com empresários, advogados, pessoal técnico, investidores-anjo, capital de risco ou mesmo executivos de empresas. As incubadoras visam organizar o processo de criação da empresa, fornecendo a estrutura física inicial, uma rede de network técnico que soma smart money e suporte.

A pré-aceleração, por sua vez, é o momento em que se seleciona as startups que irão ingressar no programa de aceleração. Está dentro de um formato temporário de seleção de empresas, visando otimizar os recursos do bootstrap, possibilitando àquele empreendedor que estava tocando a sua startup através de recursos próprios, validando a sua solução e na elaboração de um MVP, a sua inserção numa seleção para ser acelerador.

${ }^{5} \mathrm{O}$ texto original em inglês é o seguinte: "the job of an incubator has evolved from one of helping companies survive their formative years (decreasing downside risk) to one of adding value to companies (increasing upside advantage)". 
Assim, o pré-acelerador oferece um seed capital (capital semente) que é um fôlego financeiro curto injetado antes mesmo de a startup atingir o breakeven point, para que ela possa demonstrar superficialmente uma capacidade mínima de viabilidade e se tornar escalável. Caso ela seja aprovada nessa fase preliminar e for selecionada para ingressar na aceleração, a partir de então haverá um aporte maior de recursos, acesso às mentorias e a realização do equity, conforme já abordado anteriormente.

É característica marcante também da aceleração uma ascensão a um mercado mais agressivo de investidores, a exemplo do PE ou até mesmo o VC. O ponto em comum entre elas, é o fato de que todas são estruturas que visam qualificar e graduar startups, conduzindo-as a um caminho que poderia ser mais longo, se percorrido sozinho. Trata-se de agentes que visam aprimorar o projeto de negócios inovadores, melhorar a estrutura logística, humana, validar o problema e produto, para que assim possam despertar o interesse de investidores.

A "saída" é o termo utilizado para fazer menção ao ato de fundador ou investidor que se tornou sócio, retirar-se total ou parcialmente da sociedade. É o momento em que um membro do quadro social da startup, que deu sua contribuição, seja através de uma injeção de recursos financeiros, smart money ou até mesmo o idealizador do negócio, realizar a venda de seus percentuais em troca de dinheiro.

Por se tratar de um universo muito dinâmico, as pessoas que vivem uma startup têm como projeto profissional uma permanência temporária na empresa, dando a sua contribuição e posteriormente desfazendo os seus vínculos, recebendo os lucros em virtude disto, para partir para outro negócio.

Quando se tratar de investimentos realizados mediante um fundo, a data de saída geralmente estará explícita no contrato de financiamento, haja vista que o gestor do patrimônio tem um compromisso com o grupo de investidores para remunerá-los. Entretanto, essa saída é ato delicado e requer realização dentro de um timing adequado, vez que pode transmitir mensagem equivocada para o mercado, a exemplo de suspeitas quanto à saúde financeira da empresa e a sua sustentabilidade.

Investidor-anjo é a modalidade de investimento, cujo termo é de origem norte-americana Angel investor ou Business Angel, onde no início do século XX nomeava-se os investidores que bancavam os custos de produção da Broadway, assumindo os riscos e participando do retorno financeiro, e davam o suporte necessário para a sua execução (Spina, 2012, pp. 25-26).

Esse investimento é a modalidade realizada por pessoas físicas, geralmente empresários ou agentes do mercado, que já possuem experiência e conhecimento no mundo empreendedor, e que ao financiarem novas empresas, atuam não apenas no aspecto financeiro, mas agregando também seus valores imateriais, aumentando as chances de sucesso das companhias investidas, uma vez que eles passam a participar das decisões estratégicas e orientar os fundadores para seguirem o melhor caminho.

A previsão legal do investidor-anjo no Brasil foi realizada pela Lei Complementar 155 de 2016, sendo sua importância para as startups se dá pelo fato de que esse tipo de investimento agrega a essas instituições não apenas o capital, que dentro dessa realidade mercadológica passa a não ser o principal instrumento, vez que em último caso, é possível conseguir financiamentos bancários ou até mesmo com instituições públicas de fomento ao empreendedorismo. Nessa espécie de investimento, os financiadores entram também com o chamado smart money.

Em tradução para o português, o dinheiro inteligente é o material humano e intelectual capaz de catapultar o desenvolvimento da empresa, o "caminho das pedras" trazido por um investidor, empresário ou alguém do mercado, que traz na sua bagagem experiências que fortalecem e conduzem as firmas a patamares que não seriam alcançados, ou seriam atingidos a duras penas.

Como na realidade de startups há o fator do pioneirismo no modelo de negócios, onde não existe outro exemplo de sucesso até então para basear a empresa, o risco se acentua ainda mais, posto que será preciso consolidar o business plan para só então ir operar os produtos e serviços que serão ofertados. 
É no meio desse cenário que se destacam os investidores-anjos. Embora existam outras modalidades de financiamentos externos, essa espécie, para startups, é de relevância considerável, pelos motivos que seguem. O investidor-anjo é uma pessoa que possui uma experiência prévia de gestão de empresa, de maneira que se junta a outra para não investir apenas o capital, mas para agregar a sua experiência e know-how, passando a desempenhar um papel fundamental na formatação inicial da empresa que se encontra num estágio inicial de desenvolvimento.

Assim, há que se falar na função social mediata desses atores. É que reconhecendo a função social imediata das empresas, que são motores importantes de uma economia, que ao produzir riquezas, fazem dinheiro circular, geram empregos, tributos e renda, é inegável para toda a sociedade um interesse na sua preservação e no seu crescimento, pois indiretamente e em algum momento haverá benefícios para toda a sociedade.

Isso porque uma empresa que dá certo se desenvolve e cresce, em algum momento ela precisará aumentar o número de empregados. Precisará de uma instalação física que poderá ser adquirida ou alugada a um terceiro. Bens e serviços diversos serão adquiridos com outros fornecedores como um meio para atingir a finalidade dessa companhia. Além do mais, o próprio Estado passará a cobrar IPTU, encargos trabalhistas, impostos sobre a renda, e uma infinidade de tributos que incidem sobre a atividade empresarial.

A lógica para as startups, embora seja um nicho empresarial muito peculiar, permanece a mesma, posto que em alguma escala, haverá a mesma consequência. Todavia, um importantíssimo tema deve ser levantado sobre essa discussão com relação aos números.

Ao realizar inovação na maneira de empreender, é marca comum dessas empresas trabalhar com mais tecnologia que os setores tradicionais de mercado, utilizando consideravelmente de automação e inteligência artificial. Isso implica em substituição de humanos por máquinas. Atualmente, a dimensão dessa transformação ainda é pequena, mas caminha a passos largos e produzirá imprevisível impacto no mercado de trabalho.

A proporção de substituição de mão de obra humana por robôs não é proporcional à criação de novos empregos e vagas de trabalho. Quando o início desse processo aconteceu na primeira revolução industrial, o impacto provocado pela modernização foi concentrado nos trabalhos repetitivos, braçais e menos qualificados; restava ao trabalhador atingido pela modernização mudar para outra atividade econômica que não havia sido atingida, e houve uma absorção dessa mão de obra recém-desempregada em outras esferas.

Acontece que na quarta revolução industrial, vivenciada no presente momento, a robotização não atinge apenas setores menos qualificados, mas até mesmo empregos das classes mais altas, a exemplo de médicos, advogados, juízes, contadores e demais atividades fim. Assim, repartições que ainda não foram profundamente impactadas, em algum momento serão. No início, em menor grau, mas o desenvolvimento que avança de maneira exponencial tem capacidade de produzir resultados imprevisíveis e inevitáveis.

A ligação dessa discussão com o tema de startups é estreitíssima. Os incentivos ao surgimento de novos produtos, serviços e ideias revolucionárias que estão proporcionando essas mudanças, agora são muito maiores do que anos atrás. Isso porque nesse novo ecossistema de startups, possibilita pessoas completamente desprovidas de estrutura financeira acertarem a mão e construírem empresas gigantescas, realidade inatingível no empreendedorismo tradicional e engessado que dificulta a entrada de novos players fora do sistema. Exemplos de sucesso disruptivo não faltam.

Esse novo panorama não se tornou realidade porque houve uma conversão de um modelo econômico capitalista agressivo para um filantrópico que injeta capital aleatoriamente em pessoas bem-intencionadas, mas, porque investir nessas novas lideranças pode render muito dinheiro. Empresas como a Uber, o WhatsApp, o Facebook e Instagram são os exemplos de unicórnios que nasceram minúsculas e desacreditadas, mas que em pouco tempo dominaram o mercado global. 
Há que se falar ainda que inexiste um interesse da classe empregadora em ir contra essa realidade, uma vez que a longo prazo é mais barato ter como empregado um robô. Isso porque para máquinas não existem salários e os pedidos por aumentos, encargos e direitos trabalhistas jamais serão pedidos ao empregador ou a um juiz. Eles não adoecem e não têm filhos, além do que a margem de cometimento de erros se aproxima de zero.

Trata-se, portanto, de um caminho sem volta, cujas consequências são profundas e as discussões sobre a temática devem ser aceleradas. É por conta dessa previsão, que propostas como renda básica universal começam a ganhar adeptos (Roque, 2018) em todo o mundo como uma possível solução para frear a concentração de renda e a desigualdade social proporcionada pela ausência de postos de trabalhos. Entre os seus defensores, estão Marck Zuckerberg e Elon Musk, respectivamente, fundadores do Facebook e Tesla.

Em um mundo que caminha para uma população de 10 bilhões de pessoas em 2050, com a evolução da tecnologia, levando em consideração o impacto ela provocará sobre a dinâmica do mercado de trabalho, questiona-se se haverá postos suficientes para todas essas pessoas?

Contudo, o outro lado da moeda parece ser também muito positivo. Pessoas que defendem esse pensamento, Steven Kotler e Peter Diamandis, falam em uma era da abundância proporcionada por essas mudanças (Diamandis, 2018). Com a desmonetização dos serviços, redução radical dos custos e a desmaterialização, já dão sinais de que isso pode ser uma realidade benéfica. $\mathrm{O}$ crescimento exponencial de tudo, proporcionado pelo avanço da tecnologia, irá oferecer uma melhoria inimaginável na qualidade de vida dos humanos. Será possível fornecer uma gama de produtos e serviços que eram exclusivos de uma minoria abastada a todos, e com excelência muito superior.

Com o avançar da tecnologia sobre a agropecuária e as melhorias sobre a produção alimentar, tornar-se-ia possível erradicar a fome global, triste realidade bem presente nos dias atuais. Na área da saúde, a cura de doenças desconhecidas hoje, provavelmente será descoberta no médio prazo. Isso pode ser proporcionado pela robótica, inteligência artificial e supercomputadores que são capazes de processar milhões de dados em poucos segundos, procedimento que levaria séculos, se feito apenas por humanos. O uso de impressoras 3D para imprimir órgãos humanos sob medida e realizar implantes sob medida também é uma possibilidade real, acrescentando qualidade e tempo de vida para pessoas que se encontrariam em fase terminal.

O projeto genoma humano, que foi responsável entre 1990 e 2005 por sequenciar e mapear todo o DNA das células do corpo humano, já é realidade. O material genético extraído pelos cientistas, já estudado pelos diversos segmentos da ciência, contém informações que podem proporcionar isso e mudar a forma como a biologia e medicina se comportam hoje perante os fatos. Saber a maneira como o gene humano se comporta e os motivos pelos quais alguém desenvolve um câncer ou outra patologia, pode fazer com que a medicina se antecipe na cura ao invés de tratar a doença, por exemplo.

Projetos que hoje parecem intangíveis e pouco factíveis, serão realidade no futuro. É inegável o impacto benéfico que todo esse panorama trará para a humanidade. Há uma verdadeira democratização dos bens e serviços que eram possibilidades de poucos. Isso está fazendo com que pessoas hoje já comecem a se interessar mais pelo acesso à propriedade, ao usufruto e consumo dos benefícios providos por esta do que se tornarem proprietários. Não é preciso mais ter um automóvel próprio para se locomover para onde quiser e no momento que quiser, sem ter que para isso se utilizar de um transporte coletivo.

Embora já dito anteriormente, é preciso reforçar que, infelizmente, todo esse cenário positivo não parece que será promovido por uma conversão de um modelo econômico capitalista agressivo para um filantrópico, que após milênios de existência da humanidade, atingiu no século XXI a empatia e compaixão alheia. Mas, porque proporcionar esses serviços e produtos a todos será o caminho lucrativo das empresas, que movidas pelo interesse patrimonial, irão descobrir e proporcionar essa qualidade de vida a todos como consequência da busca pelo ágio. Será um benefício proporcionado por interesses puramente monetários. 
Toda essa nova realidade social, econômica e jurídica, é proporcionada por esse novo empreendedorismo das startups. São elas os motores e o combustível dessa revolução que se vivencia atualmente. Nesse sentido, há sobre os investidores-anjos uma função e interesse social para que do smart money que eles podem proporcionar a essas empresas, mais companhias tenham sucesso e façam com que a roda da economia possa girar, beneficiando toda a sociedade.

Frise-se também que, em detrimento desse interesse coletivo mediato sobre esse financiamento, deve ocorrer nesta relação de investimento, guardadas as devidas proporções, a respectiva e proporcional responsabilidade, evitando-se que todo o ônus dessa relação recaia sobre o investido, que ocupa no caso do investimento-anjo, posição mais vulnerável em relação ao financiador.

Isso porque a startup que procura essa modalidade de investimento, é porque não dispõe no time original das habilidades necessárias para organicamente alcançar o desenvolvimento necessário e busca no mercado essas ferramentas.

Assim, o anjo chega com o capital, mas também com os dispositivos intelectuais de know how, conhecimento de mercado, administrativo e jurídico, em uma companhia em que muitos são marinheiros de primeira viagem, de modo que está configurada a situação perfeita para aqueles que tiverem interesse em se portar de má-fé.

Há, portanto, inegável assimetria entre as partes desse eventual contrato. De um lado, há o investidor que dispõe do capital e, presumidamente, do conhecimento e domínio das regras do jogo, enquanto do outro, há o investido, muitas vezes necessitado financeiramente e buscando suprir também as suas carências imateriais.

Deve-se sopesar, também, o fato de que viver em uma sociedade capitalista impede que as pessoas vivam apenas de ideias, e torná-las realidade importa em dispender capital e recursos financeiros, os quais são conquistados a duras penas. Assim, deve haver um benefício atrativo para aquelas pessoas que se propõem a injetar patrimônio pessoal em ideias e interesses alheios, tornando possível algo que poderia jamais existir.

Realizar esse balanceamento de interesses é tarefa de extrema dificuldade, posto que não poderá onerar excessivamente o investido, sob pena de violar valores como o da boa-fé objetiva, dignidade da pessoa humana, equidade e justiça social. Enquanto que do outro lado, a proteção estatal excessiva a esse ator tornaria o mercado pouco atrativo para investidores, que por ser uma ferramenta propulsora fundamental, poderia emperrar a engrenagem que faz a economia girar, e que indiretamente traz inúmeros benefícios para toda a sociedade.

Registre-se que investidor-anjo é um nome didático para a pessoa física ou jurídica que ingressa em um empreendimento com capital financeiro, mas principalmente com o smart money. Não se trata de um contrato, mas sim de uma modalidade de investimento. Sem embargo, existe regramento específico estabelecido pela LC 155/16 a qual criou mais uma opção para a contratação desse investimento, trazendo ao mundo jurídico a figura do contrato de participação.

\section{Considerações Finais}

Ante o exposto, é possível extrair que diante o cenário de grandes riscos e incertezas, a startup precisará de capital de terceiros para começar a operar, o que faz com que nesse meio, a prática do bootstrapping seja muito comum.

Ademias, há que se destacar também o grau de relacionamento entre o investidor e o investido nessa qualidade de financiamento. Não há limitação apenas a valores pecuniários, posto que o anjo desempenhará um papel de orientação e apoio do negócio daquele. Enquanto o investidor tradicional se relaciona com o investido exclusivamente sob o viés financeiro, na modalidade do financiamento-anjo extrapola-se esse parâmetro do simples auxílio econômico.

Nesta esteira, levando em consideração essa necessidade de assegurar, de forma eficaz, o desenvolvimento econômico inerente ao mercado, acreditamos que investigações como esta devem ser prosseguidas. Sendo assim, como sugestão para continuidade de discussões nesse sentido, analisar, à luz do Direito Empresarial, de que modo os contratos empresarias podem 
Research, Society and Development, v. 10, n.6, e35610613654, 2021

(CC BY 4.0) | ISSN 2525-3409 | DOI: http://dx.doi.org/10.33448/rsd-v10i6.13654

ser implementados com o fito de melhor exercer sua função impulsionadora, contribuirá para o fortalecimento e planejamento de estratégias de atenção aos empresários do ramo em questão.

\section{Referências}

Agência Brasileira de Desenvolvimento Industrial. (2011). A Indústria de Private Equity e Venture Capital: $2^{\circ}$ censo brasileiro. Brasília: ABDI.

Condé, M. (2015). Pratique Bootsrapping (alça de bota) - A arte de sobreviver em tempos difíceis e fazer o seu dinheiro render mais: Como agir em tempos de crise na sua vida pessoal e na sua empresa, copiando as melhores práticas das pessoas e empresas que melhor sobrevivem nestes momentos: MaLuCo. 28 ago. 2015. http://oblogdomaluco.com.br/pratique-bootsrappingalca-de-bota-a-arte-de-sobreviver-em-tempos-dificeis-e-fazer-o-seu-dinheiro-render-mais-comoagir-em-tempos-de-crise-na-sua-vida-pessoal-e-na-sua-empresa-copiando-as-melhor/

Diamandis, P. H., \& Stven, K. (2018). Abundancia: o futuro é melhor do que você imagina. Tradução de Ivo Korytowski. Rio de Janeiro: Alta Books.

Feigelson, B., Fontenele, E., \& Fonseca, V. C. (2018). Direito das Startups: Saraiva Educação.

Gitahy, Y. (2018). Como pivotar sua startup pode expandir seus negócios. http://www.sebrae.com.br/sites/PortalSebrae/artigos/por-que-voce-deve-pivotar-suastartup,b5192bf060b93410VgnVCM1000003b74010aRCRD

Loureiro, R. (2018). O prejuízo bilionário da Uber. https://www.istoedinheiro.com.br/o-prejuizo-bilionario-da-uber/

Miller, P., \& Bound, K. (2011). The Startup Factories: The rise of accelerator programmes to support new technology ventures. http://www.eban.org/wpcontent/uploads/2014/09/14.-StartupFactories-The-Rise-of-Accelerator-Programmes.pdf

Roque, T. (2018). Por causa de robôs, ideia de renda básica universal ganha mais adeptos. https://www1.folha.uol.com.br/ilustrissima/2018/02/por-causa-derobos-ideia-de-renda-basica-universal-ganha-mais-adeptos.shtml\&gt

TESLA. (2018). TESLA tem prejuízo maior que o esperado, mas anima investidores com promessa de lucro. https://link.estadao.com.br/noticias/empresas,teslatem-prejuizo-maior-que-o-esperado-mas-anima-investidores-com-promessa-de-lucro,70002426188

Uber. (2018). Uber recebe aporte de US\$ 3,5 bilhões de fundo da Arábia Saudita. Newswires, Dow Jones. https://www.valor.com.br/empresas/4586185/uberrecebe-aporte-de-us-35-bilhoes-de-fundo- da-arabia-saudita\&gt; e https://exame.abril.com.br/negocios/com-aporte-de-us-2-1-bi-uber-ja-vale-mais-que-fordou-gm/

Viana, A. (2018). Bootstrapping: Como Manter Sua Startup Sem Investimentos Externos. https://www.outboundmarketing.com.br/bootstrapping/ 